\title{
Direct landfill disposal versus Mechanical Biological Treatment (MBT)
}

\section{Bezpośrednie deponowanie na składowisku a mechaniczno- biologiczne przetwarzanie odpadów (MBP)}

*Mgr Katarzyna Kulhawik - Faculty of Geographical and Geological Sciences, Adam Mickiewicz University in Poznań, Dzięgielowa 27 St., 61 - 680 Poznań, e-mail: katarzyna.kul@poczta.onet.pl

Keywords: landfill, biogas, leachate, threats to the environment, mechanical-biological processing (MBP), recovery, safe disposal Słowa kluczowe: składowisko, biogas, odcieki, zagrożenie dla środowiska, instalacja MBP, odzysk, bezpieczne unieszkodliwianie

\begin{abstract}
After the implementation of a new waste management system, in which recycling is the most dominating process, landfill disposal still appears to be the most popular method of waste management in Poland, in which waste undergoes gradual decomposition and the influence of climate conditions, for example, air and atmospheric fallout, leads to the production of leachate and biogas emissions, which contribute to continual threats to the natural environment and humans. The above-mentioned threats can be limited by applying suitable techniques of waste treatment before its disposal. A technology that is oriented to these aims is a mechanical biological treatment (MBT) before disposal.

The above-mentioned technology results is waste stabilisation and reduction of pollutant emissions. Additionally, it allows to increase the recovery of materials for recycling and to reduce the mass of waste. Finally, it is environmentally friendly.
\end{abstract}

๑) IOŚ-PIB

\section{INTRODUCTION}

The waste management system in Poland was not very effective for a long time. There was not a suitable recycling system; the amount of landfill waste was constantly increasing. Therefore, on 1 July 2011, an Act was passed on amendments to the act on maintaining cleanliness and order in communes, which has changed the former system of municipal waste management. According to the new system, recycling is regarded as priority, whereas disposal is the last resort. Unrecyclabe waste should 'still' be disposed to landfill. From the technical point of view, landfill disposal should be a process in order to limit its impact on the natural environment and people. Nevertheless, numerous research conducted over the years confirm that landfills create a potential threat to the environment (by virtue of leachate production and biogas emission) [Rosik-Dulewska 2015]. In order to reduce the above-mentioned threats, mechanical biological processing is becomming more and more common in Poalnd. The MBP technology is applied by Regional Waste Management Companies as the most affective and available technology [NWMP 2014].

\section{Streszczenie}

Po wprowadzeniu nowego systemu gospodarki odpadami, gdzie dominującym procesem ma być odzysk, nadal najpopularniejszą metodą zagospodarowania odpadów w Polsce jest ich deponowanie na składowiskach. Zdeponowane odpady podlegają powolnemu procesowi rozkładu a oddziaływanie warunków klimatycznych tj. powietrza i opadów atmosferycznych generuje odcieki oraz emisję biogazu, które powodują ciągłe zagrożenia dla środowiska naturalnego i człowieka. Zagrożenia w/w można ograniczać, stosując odpowiednie techniki przetwarzania odpadów przed ich składowaniem. Technologią ukierunkowaną na osiągnięcie tych celów jest mechaniczno-biologiczne przetwarzanie odpadów (MBP) przed ich składowaniem.

Efektem w/w technologii jest stabilizacja odpadów prowadzącą do zmniejszenia emisji zanieczyszczeń. Ponadto pozwala zwiększyć odzysk materiałów do recyklingu oraz zmniejszyć masę deponowanych odpadów. W efekcie końcowym jest bezpieczna dla środowiska.

Taking above into consideration, the study contains differences (characteristic) between direct disposal to landfill and mechanical biological processing.

\section{THE FUNCTIONING OF LANDFILL SITES}

\subsection{Landfill disposal}

In Poland, in 2010, according to the Central Statistical Office [Environment 2010], 80\% of the mass of collected municipal waste was disposed in landfills. In the new member states, waste disposal is still dominant (from $62 \%$ in Slovenia to $100 \%$ in Bulgaria). Nevertheless, the Eurostat data for 2010 indicates that many European countries, under EU law, depart from waste disposal. In Austria, Belgium, Denmark, the Netherlands, Switzerland and Sweden, waste disposal does not exceed 5\% of the overall balance of waste processing [Białowiec 2012]. It is a result of technology development, namely a mechanical biological treatment (MBT). 
Waste disposal, along with the increase in awareness of threats to the environment, has undergone specific revolution, starting from the most primitive form based on throwing waste away at random, unprepared places to highly advanced technologies of waste disposal.

At present, a landfill site [Act... 2012] is a structure that is located and built in accordance with the regulations meant for waste disposal of known properties. According to the latest technology, a landfill site is a bioreactor with complicated surface and wall seal, containing a system of intakes and waste treatment and a system of intaking and using biogas.

Complying with the EU requirements, waste landfills should ultimately be meant for disposal of residues coming from the recovery process and rendering harmless, namely burning, composting and, finally, complex processing including preliminary segregation, methods of biological and thermal waste processing. For example, after composting, there remains by weight approximately $38-50 \%$ and after burning, approximately $10-20 \%$ of waste requiring to be disposed.

At the end of 2012, in Poland, there were 527 active and controlled landfill sites meant for municipal waste. They covered the total area of 2,198 ha. During 2012, 61 landfill sites of 132 hectares were closed [Municipal infrastructure in 2012].

\subsection{Consequences of waste disposal}

From the technological point of view, waste disposal is a process of waste dumping in order to reduce its impact on the environment and people, which should, however, be under control. As a result of conducted research over the years, it has been confirmed that the processes that take place in landfill sites are usually out of control. It mainly refers to the processes of biogas production and to the control of leachates production and management.

Biogas is generated as a result of waste decay under oxygen-free conditions, which exist in the layers of disposed waste, whereas leachates appear when atmospheric fallout soaks through the landfill layer. They can also come from surface and underground water, which flow to the deposits of waste and slightly constitute the composition of the waste (coming from the decay of organic substances). Leachates contain a significant amount of pollutants (fluctuating from a few hundreds to a few hundred thousands $\mathrm{O}_{2}$ as $\mathrm{CHZT}$ and BZT 5), which by infiltrating through the sphere of aeration are likely to get to the underground water and migrate to considerable distances. Spreading of pollution in the underground water depends on volume and quality of leachates, purifying properties of the zone of aeration and saturation, speed and intensity of flow and type of soil.

Taking above into consideration, landfills constitute a 'potential' threat to the environment; however, if they are built according to the current technology, they can be operated in such a way so as to eliminate the environmental nuisance significantly (e.g. leachates, arduous smells, fire hazards).

Owing to the harmfulness, landfills should fulfil technical demands that are defined by the law, namely [Rosik-Dulewska 2015]

- a system of underground and surface water protection against waste (seal),

- a system of leachate drainage,
- a system of biogas production and management,

- technological equipment for forming and compacting (and covering with damp courses consecutive waste layers),

- a system of permanent control of the impact of landfills on the environment (monitoring),

- a reclamation system.

\section{THE FUNCTIONING OF A MECHANICAL BIOLOGICAL TREATMENT}

\subsection{A mechanical biological treatment as the basis for a new system of waste management}

Poland as a member state is obliged to fulfil EU's obligations. The former waste management system in Poland was not very effective. A suitable recycling system was absent; the mass of waste disposed to landfill was constantly increasing. Furthermore, the approaching date for fulfilling the EU's obligations revealed that the matter was really serious and required prompt solutions. Therefore, on 1 July 2011, an Act was passed on amendments to the act on maintaining cleanliness and order in communes and to some other acts, which following the example of other European states changed the former system of municipal waste management. The Act has introduced such significant changes in the system of municipal waste management that it is called 'waste revolution'.

According to the 'new system', recycling is the priority, whereas disposal is the last resort (according to the former system, it was the disposal which was the priority). The goal is to maximise the recovery of waste material and energy in order to obtain the required quality of waste for recycling. To achieve the goal, selective collection of some fractions is essential. However, the waste that is not subject to recovery must undergo the biological mechanical treatment in a Waste Management Company before it is finally sent for disposal.

According to the above-mentioned basis of the system of municipal waste management (according to the national waste management plan), Regional Waste Management Companies having capacity sufficient to take and process waste from areas inhabited by more than 150,000 people in compliance with the most efficient techniques are in charge thereof.

The companies should provide at least the following scope of services [NWMP 2014]:

mechanical and biological or thermal processing of mixed municipal waste and residues from the sorting plant,

- disposal of the processed mixed municipal waste,

- composting of green waste,

- sorting of some fractions of municipal waste collected selectively (optionally)

- large waste dismantling facility (optionally),

- $\quad$ recycling facility for waste electric and electronic equipment (optionally).

In case of agglomeration or regions of more than 300,000 inhabitants, thermal waste processing is considered to be the most effective method of mixed municipal waste management, whereas in case of smaller regions, mechanical and biological methods appear to be better. 
Table 1. Basic objectives and elements of the MBT facilities.

\begin{tabular}{|c|c|c|c|}
\hline No & Types of MBT options & Objectives of MBT options \\
\hline 1 & Waste stabilization before its disposal & Reducing susceptibility of municipal waste to biological decay and recovery of \\
some recyclable waste
\end{tabular}

Source: [Białowiec, Wojnowska-Baryła 2012]

It is worth considering that the entity that collects municipal waste must send collected selective waste to the disposal or recovery facility, whereas mixed municipal waste, green waste and residues from sorting municipal waste to the Regional Municipal Waste Processing Facility [Bujny 2014].

\subsection{Mechanical Biological Treatment (MBT)}

MBT derives from German experience in composting mixed municipal waste. A number of pilot projects whose objective was to process waste applying mechanical and biological methods before its disposal in order to reduce its nuisance to the environment were created not later than in 1970s. The first generations of MBT were very simple sorting plants related to compost piles, in which waste was prepared for dumping [Jędrczak 2007].

At present, a significant number of MBT facilities are being built, developed and modernised in accordance with the Waste Management Act and relevant regulations of provincial waste management plans.

In Poland, in 2012, 117 MBT facilities were operated, with the capacity of the mechanical part equal to $7.97 \mathrm{mln} \mathrm{Mg}$ and the biological part $3.06 \mathrm{mln} \mathrm{Mg}$. Another 80 were under construction or just designed. Their capacity is estimated as $4.4 \mathrm{mln} \mathrm{Mg}$ for the mechanical part and $1.86 \mathrm{mln} \mathrm{Mg}$ for the biological part [Jędrczak 2014].

It is worth mentioning that MBT is widely applied in Europe. Austria and Germany are considered to be the leaders amongst the member states in this respect.

The technology was indicated in the National Waste Management Plan 2014 as recommended for regions inhabited by more than 150,000-300,000 people.
MBT refers to general technology that consists of facilities for mechanical sorting of waste related to facilities for biological stabilisation of streams of biodegradable waste. The stage of mechanical sorting can take place at the beginning of the MBT process (biostabilisation) or after the biological process (biodrying).

There are many MBT strategies. The most common are the eight most frequently applied options (Table 1) [Białowiec, WojnowskaBaryła 2012].

\subsubsection{Mechanical processing}

Mechanical sorting is the first step in the MBT followed by biological stabilisation of the emitted organic fractions.

The mechanical processes comprises reducing size, sieving, sorting, classification and separation. It is supposed to lead to mechanical separation of waste flows into fractions that will be partly or completely fit for material, energetic use and into biodegradable fractions for biological processing under aerobic and oxygen-free conditions [Rosik-Dulewska 2015].

Mechanical waste processing is based on sorting mixed municipal waste into minimum two granulometric fractions [Jędrczak, Szpadt 2008]:

- $\quad$ the fraction remaining on the sieve (mesh fractions) - high calorie, from which some recyclable waste is separated, and the remaining part will be sent for further processing to receive alternative fuel.

- $\quad$ subsieve fraction (sieving) is sent completely for biological processing.

Mechanical processing line for sorting of

- mixed municipal waste

- recyclable waste from selective waste collection at source. 
The applied technology makes it possible to

- select basic recyclable waste from the mixed waste flow,

- clean waste from the selective collection,

- emit organics of the fraction of about $0-80 \mathrm{~mm}$ in size as material for the stabilisation process

_ $\quad$ isolate ballast for dumping.

It is worth mentioning that because of sorting (sieving), the classification of mixed municipal waste changes from 200301 to waste marked as $191212_{2}$ the so-called ballast [Regulation ...2014] - 'other waste' (including mixed substances and objects) from mechanical processing other than named in 1912 11", which is still dumped.

\subsubsection{Biological processing (composting)}

As Poland must meet the requirements imposed by EU regulations concerning the reduction of biodegradable waste going to landfill, biological processing of the organic fraction emitted from mixed municipal waste appears to be essential.

Composting is a biological method of processing organic waste applied within the processes, namely,

- R 3 - Recycling or recovery of organic substances, which are not used as dissolvents (including composting and other biological processes of treatment)

- D 8-Biological treatment that leads to the formation of final compounds and mixtures, which are meant for disposal by any processes as named in items D 1-D 12 (the processes are in accordance with Annex 2 to the Waste Management Act).

The process of biological treatment (composting) takes place under aerobic and oxygen-free conditions.

Processes of biological treatment take place under aerobic conditions and are conducted according to the following requirements (they are recommended to be conducted for 8-12 weeks): waste is processed by turning it for at least 2 weeks, the process takes place in a closed reactor or in a hall (with active aeration, with protection that does not let_unpurified process air to enter the atmosphere, until it reaches the value of AT4 - known as the breathing activity, namely a parameter that indicates how much oxygen is needed by a waste sample during 4 days below $20 \mathrm{mg} \mathrm{O}_{2} / \mathrm{g}$ of dry mass) and for 6-10 weeks in piles placed on a leak-proof surface equipped with a leachate management system and aerated by turning waste at least once a week.

The process of biological treatment under oxygen-free conditions takes place in a two-stage process. The first stage comprises mesophilic digestion for at least 20 days or thermophilic digestion for at least 12 days. The second stage includes aerobic digestion in a closed reactor or in a hall, with active aeration, with protection that does not allow the unpurified air enter the atmosphere for at least 2 weeks. During the second stage of aerobic stabilisation, stabilisation in piles in free land is permitted, aerated by moving the waste at least once a week, for at least 3 weeks.

Composting is a controlled process of decay and stabilisation of organic substrates [Szpadt, Jędrczak 2008]. A product rich in humic and biegonic substances, the so-called stabilised compost, is the effect of the process (waste code 1905 99) (stable enough) sent mainly for disposal without hazardous impact on the environment.

The process of biological treatment of mixed municipal waste should be managed so as the received stabilised compost could finally fulfil the following requirements:

1. the loss on ignition of stabilised compost is less than $35 \%$ and the content of organic carbon is less than $20 \%$ d.m.

or

2. the loss of organic matter in the stabilised compost towards the organic mass in waste, measured with the loss on ignition or with the content of organic carbon, is more than $40 \%$,

or

3. AT4 value is less than $10 \mathrm{mg} \mathrm{O} / \mathrm{g} \mathrm{d}$. .

The so-called compost is also likely to be produced during the process (waste code 190503 ) if it is of proper quality (classified in accordance with binding regulations as an organic fertiliser), then it can be applied as a fertiliser for non-agricultural soil (in agriculture). Moreover, it can be used as humus, nutrient, soil additive or a component of plant substrates and soil culture.

\subsection{Effects (advantages) of MBT}

The following are the basic effect of MBT:

- $\quad$ Stabilisation. There is always waste in the MBT that needs disposal. New waste - stabilised compost - is formed in the process. The objective of stabilisation is minimalisation of the impact of treated organic waste on the environment. According to Stegmann research, intensive waste composting allows to reduce the emission of landfill gas and nitrogen in leachate, if the waste composting is managed properly, even by $89-90 \%$ compared to the emission from untreated waste [Sidełko, Szymański i inni 2012].

Compost is also likely to be created during the process if it is of proper quality (classified in accordance with binding regulations as an organic fertiliser), then it can be applied as a fertiliser for soil enhancement (in agriculture).

- $\quad$ Reducing the waste flow by mechanical emission of usable and energy fractions. The MBT facilities contribute to the increase in the amount of recyclable material and to the reduction of the mass of landfill waste (from $30 \%$ to $50 \%$ ) [Suchowska-Kisielewicz 2011]. If the subsieve fraction undergoes the thermal waste processing, the landfill can be unburdened by even $70 \%$.

- The increase in the susceptibility of waste after the biological treatment to compacting in landfills (it allows to save up to $60 \%$ of the landfill capacity). 


\section{CONCLUSIONS}

A campaign whose purpose is to draw social attention to the issue of threats of waste disposal to the environment has been launched recently. Dumped waste undergoes a slow process of decay. The influence of climate conditions, for example, air and atmospheric fallout, leads to the production of leachate and biogas emissions. Even though numerous attempts aimed at the reduction of the mass of waste disposal are promoted, landfills will not be eliminated totally from the landscape. The main objective should be based on safe waste treatment in order to protect the

\section{REFERENCES AND LEGAL ACTS}

Act on maintaining cleanliness and order in communes of $1^{\text {st }}$ July 2011 (The Journal of Laws of 2011, No. 152, item 897) (,,In Polish").

Act on waste management of $14^{\text {th }}$ December 2012 (The Journal of Laws of 2013, item 21). (,,In Polish”).

BIAŁOWIEC A., WOJNOWSKA-BARYŁA I. 2012. Municipal Review. MBT- technological determinants. Publisher Abrys. Poznań, 2: 34-37 (,,In Polish”).

BIAŁOWIEC A. 2012. Municipal Review. Waste landfills underestimated technology. Publisher Abrys. Poznań, 4: 4245 (, ,In Polish”).

BUJNY J. 2014. Municipal Review. Dominating position of the Regional Municipal Waste Processing Facility. Publisher Abrys. Poznań, 9: 30-32 (,,In Polish”).

Municipal infrastructure in 2012. Central Statistical Office (GUS) 2013. (, In Polish”).

JĘDRCZAKA. 2007. Biological Waste Treatment. PWN, Warsaw. (,,In Polish").

JĘDRCZAK A. 2014. Municipal Review. The condition of municipal waste management in the country._Publisher Abrys. Poznań, 7: 4-10. (,,In Polish”). environment, people and their health, which can be achieved by applying the MBT facilities. The result of the above-mentioned technology is stabilisation leading to the reduction of pollutants, such as leachates and gas up to $90 \%$, and contamination of leachates with organic substances up to $80-90 \%$ and respiratory activity of waste up to $80-90 \%$. Moreover, it contributes to the increase in processing recyclable materials and to the reduction of mass of dumped waste (from $30 \%$ to $50 \%$ ). Finally, it should lead to the reduction of biodegradable waste disposal and fulfilment of certain stages of recycling of packaging waste.

JĘDRCZAK A., SZPADT R. 2008. Guidelines on the requirements for the processes of composting, fermentation and mechanical-biological waste treatment. The Ministry of Environment. (,,In Polish")

http://www. mos.gov.pl/g2/big/2009_07/ffc492d741b261340b 1 e263cd 1 c05c85 .pdf

National Waste Management Plan 2014. (NWMP 2014). Resolution No. 217 of the Council of Ministers of 24 December 2010. (M.P. No. 101, item 1183). (,,In Polish”)

Environment. Central Statistical Office (GUS) 2010. (,In Polish”) ROSIK-DULEWSKA CZ. 2015. Rudiments of waste management. PWN, Warsaw. (,,In Polish”)

Regulation of the Minister of Environment of $\mathbf{9}^{\text {th }}$ December 2014 on waste catalogue (The Journal of Laws of 2014, item 1923). (, In Polish")

SIDEŁKO R., SZYMAŃSKI K., SEWERYN K. 2012. Municipal Review. Composting organic fractions of municipal waste. Publisher Abrys. Poznań, 1: 46-48 (,,In Polish”)

SUCHOWSKA-KISIELEWICZ M. 2011. Municipal Review. Aerobic waste decay before its disposal. Publisher Abrys. Publisher Poznań, 10: 26-29 (,,In Polish”) 